This item was submitted to Loughborough's Research Repository by the author.

Items in Figshare are protected by copyright, with all rights reserved, unless otherwise indicated.

Spenser's nationalistic images of beauty: the ideal and the other in relation to Protestant England and Catholic Ireland in The Faerie Queene Book 1

PLEASE CITE THE PUBLISHED VERSION

http://recherche.univ-montp3.fr/cahiers/

PUBLISHER

C Cahiers Élisabéthains, a Biannual Journal of English Renaissance Studies

VERSION

VoR (Version of Record)

LICENCE

CC BY-NC-ND 4.0

REPOSITORY RECORD

Fitzpatrick, Joan. 2019. "Spenser's Nationalistic Images of Beauty: The Ideal and the Other in Relation to Protestant England and Catholic Ireland in the Faerie Queene Book 1". figshare.

https://hdl.handle.net/2134/6451. 
This item was submitted to Loughborough's Institutional Repository (https://dspace.lboro.ac.uk/) by the author and is made available under the following Creative Commons Licence conditions.

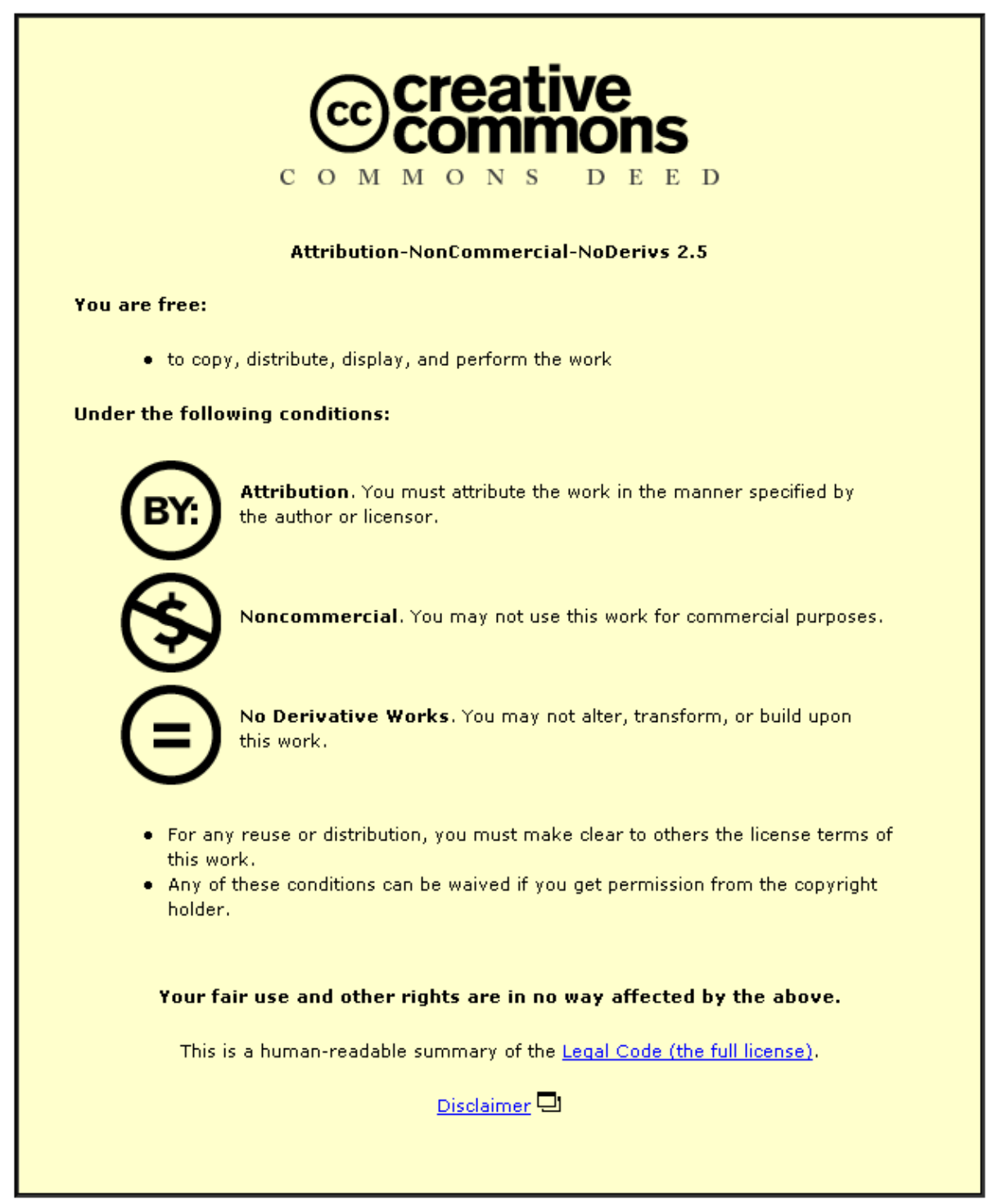

For the full text of this licence, please go to: http://creativecommons.org/licenses/by-nc-nd/2.5/ 


\section{SPENSER'S NATIONALISTIC IMAGES OF BEAUTY: THE IDEAL AND THE OTHER IN RELATION TO PROTESTANT ENGLAND AND CATHOLIC IRELAND IN THE FAERIE QUEENE BOOK 1}

Traditional interpretations of Spenser's allegory, both moral and historical, have tended to identify Una as "Truth", specifically the truth of the Reformed Church. Duessa, her opposite, has been identified as the whore who symbolizes Roman Catholicism, whilst Error has been interpreted as religious error, the enemy of the true word (heresy), or more generally as falsehood and sin. ${ }^{1}$ This paper explores Spenser's demonization of the Catholic Irish in The Faerie Queene and A View of the Present State of Ireland (hereafter the View), attributed to Spenser since $1633 .{ }^{2}$ By no means do all the demons in The Faerie Queene represent Irish Catholics, but there is evidence of a particularly Irish Catholic dimension to Spenser's depiction of Una, Duessa, and Error.

In Book 1 of The Faerie Queene images of beauty are used by Spenser to endorse the status of Elizabeth I as head of the Protestant church and grotesque images are used to demonize the enemies of that church, and of Elizabeth. Spenser builds on the figure of Elizabeth as divine representative of Protestant reform to endorse his militant Protestant position throughout Book 1. In his delineation of the grotesque physical appearance of Una's enemies, Spenser illustrates the contemporary demonization of two groups: women and the colonized Irish (including Irish women), both constructed as the Other. ${ }^{3}$ Such demonization is explicit in the View and is a feature of other colonialist writings. Spenser depicts the evil which he believes threatens the English Protestant state as sexually and morally degenerate. 


\section{Una and Elizabeth}

It is now generally accepted that in Book 1 of The Faerie Queene Spenser alludes to the New Testament Revelation of St. John. In his Observations on the Fairy Queen of Spenser (1762), Thomas Warton identified such allusions and dismissed them as impious. The Variorum edition of Spenser's works does not, however, include the Revelation amongst its list of the sources of Book 1 (Greenlaw, I, pp. xi-xii). Josephine Waters Bennett in The Evolution of The Faerie Queene (1942) was the first to suggest the primacy of this source for Book 1 , both structurally and allegorically. She showed that the Revelation was interpreted in the Renaissance as a prophecy of Protestant Reformation and an allegory of conflict with the Roman Catholic church. ${ }^{5}$ Such an interpretation is evident in the commentary of the 1560 edition of the Geneva Bible, which Spenser certainly would have known. This was the most popular English version of the Bible from 1576 until the outbreak of the Civil War in $1642 .{ }^{6}$

Religious conflict provides the overall structure which organizes Book 1. Una is identified by Spenser as "Truth" (I.2. argument) and her function is to demonstrate the Neoplatonic ideal of womanhood. Her beauty is a manifestation of her moral and spiritual goodness but in the context of historical allegory she can also represent the figure of Elizabeth, the representative of Protestant Truth. Her name suggests oneness; she stands for the one true religion and must defend it from the duplicity of the Roman Catholic church. Of course Queen Elizabeth as defender of the Protestant faith against the Papists is an obvious parallel. Her motto was Semper Eadem, a Latin phrase meaning "Always the same", and a translation of an English motto "Be always one". "Una is also a common Irish name ${ }^{8}$ and thus Elizabeth's authority in Ireland, or the lack of it, is brought into focus. Una represents the Protestant church and state which, by the agency of Elizabeth's representatives, must free Ireland from the grip of Roman Catholicism. Redcrosse represents Holiness but he also personifies England and as an allegory of Saint George, Book 1 is a reminder that Elizabeth is the divine representative of Protestant reform.

When Una first appears she is not named but is described with great attention to iconographical details:

A louely Ladie rode him faire beside, Vpon a lowly Asse more white then snow, Yet she much whiter, but the same did hide

Vnder a vele, that wimpled was full low, And ouer all a blacke stole she did throw, As one that inly mournd: so was she sad, And heauie sat vpon her palfrey slow;

Seemed in heart some hidden care she had, And by her in a line a milke white lambe she lad. $(\text { I.1.4.1-9 })^{9}$ 
She is strongly associated with whiteness, denoting virginity and purity, which is another link with Elizabeth the "Virgin Queen". Una is dressed in white and black which were, as Roy Strong has shown, Elizabeth's personal colours worn by her champions in the tiltyard and by dancers in court masques. ${ }^{10}$ Una is also the ideal Petrarchan lady - fair skinned with fair hair-and is a source of physical lightness and brightness throughout Book 1. She is compared to the physical brightness of the sun: 'The blazing brightnesse of her beauties beame, / And glorious light of her sunshyny face' (I.12.23.1-2), but is also a source of spiritual light: 'Her angels face / As the great eye of heauen shyned bright, / And made a sunshine in the shadie place' (I.3.4.6-8). This similarly is a link with the Woman Clothed with the Sun in the Revelation: 'And there appeared a great wonder in heauen: A woman clothed with the sunne, \& the moone was vnder her feete, and vpon her head a crowne of twelue starres' (12:1). ${ }^{11}$ As Helen Hackett notes, contemporary Protestant commentators identified Elizabeth with the Woman Clothed with the $\mathrm{Su}^{\mathrm{n}} 12$ The nationalistic identification can be taken further. In Spenser's depiction of Una there are connotations of purity, the Anglo-Saxon uncontaminated by darker elements of the kind that attempt contamination throughout Book 1.

Una's association with the land of Eden, via her parents Adam and Eve, prefigures Irena as a personification of Ireland in Book 5. To a degree Una also is an idealized allegorical representation of Ireland. Critical discussion of Spenser's allusions to Ireland in The Faerie Queene usually focuses on Book 5 where Artegall, the knight of Justice, frees Irena from the grip of Grantorto, the giant who represents Catholic power. Irena is an anagram of Ierna which, according to William Camden, was the Classical name for Ireland. ${ }^{13}$ It is also important to note that Irenius, the masculine form of Irena, is generally considered to be Spenser's spokesman in the View. ${ }^{14}$ Yet Ireland is also alluded to in Book 1. If Una can be said to denote the actual land in some way then what occurs is a sexualizing and gendering of the colonized landscape. There is an emphasis on Una's white clothes, her white horse and lamb, and her pale skin. A pale complexion, which could give the impression of a green tinge, was often identified with green sickness, an anaemic disease commonly attributed to a virgin's sexual fantasies which manifested itself through an unhealthy pallor and could only be cured by a sexual encounter. ${ }^{15}$ In Luke Gernon's A Discourse of Ireland, Ireland itself is conceptualized as a young woman suffering from this ailment. Although later than The Faerie Queene, Gernon's gendered personification of the colonized land is illuminating for the connection it draws between the act of appropriating land and the construction of that land as young, female, pale, and very beautiful:

This Nymph of Ireland, is at all poynts like a yong wenche that hath the greene sicknes for want of occupying. She is very fayre of visage, and hath a smooth skinn of tender grasse. Indeed she is somewhat freckled (as the Irish are) some partes darker than other. Her flesh is of a softe and delicat mould of earthe, and her blew vaynes trayling through every part of her like ryvoletts.... 
Her bones are of polished marble, the grey marble, the blacke, the redd, and the speckled, so fayre for building that their houses shew like colledges,... Her breasts are round hillockes of milkyeelding grasse, and that so fertile, that they contend $\mathrm{w}^{\text {th }}$ the vallyes. And betwixt her leggs (for Ireland is full of havens), she hath an open harbor, but not much frequented.... It is nowe since she was drawne out of the wombe of rebellion about sixteen yeares, by'rlady nineteen, and yet she wants a husband, she is not embraced, she is not hedged and diched, there is noo quicksett putt into her.

Ireland's harbour being 'not much frequented' suggests that it has been visited at least once before, by the Anglo Normans in the twelfth century. Yet the land is still not conquered and so, like a virgin, it has yet to be husbanded. The 'yong wenche' suffering from green sickness needs the controlling influence of a husband, and Ireland is penetrated with a Protestant sword in an attempt by the English to impose control on it. ${ }^{17}$ The trope of the colonizer as husbandman and the allusion to enclosure is an intentional link between the cure of a "husband" and "husbandry" as a synonym for farming and careful management. Spenser identifies Una with the physical land of Ireland and at the same time, as a surrogate of Elizabeth, she is the rightful ruler of that land. The fusion of ruler and land to be ruled was made explicit in the naming of the colony of Virginia which identified the land with Elizabeth, the virgin queen, and simultaneously asserted her right to govern it. Elizabeth's motto Semper Eadem (always one) implies fusion in her royal body of the separate and typically gendered identities of land as female and monarch as male ruler of that land.

The woman-as-land trope is not peculiar to Ireland, being also evident in colonialist discourse of the New World. An important distinction between the colonial experience in Ireland and in the New World was that the latter was virgo intacta. Whilst Ireland's harbour is said by Gernon to be 'not much frequented', the harbours of the New World had not been frequented at all. The land as a green-sick virgin ripe for penetration is evident in Raleigh's famous description of Guiana as 'a Countrey that hath yet her Maydenhead'. ${ }^{18}$ Louis Montrose points out that Raleigh's metaphor of Guiana's maidenhead 'activates the bawdy Elizabethan pun on countrey, thus inflaming the similitude of the land and a woman's body, of colonization and sexual mastery'. ${ }^{19}$ Other examples of colonized land represented as a naked female can be found in Ripa's book of moral emblems, Iconologia, which depicts a female America and Africa as 'almost naked' whilst significantly Europe, also personified as female, is richly clothed. $^{20}$ Donne's Elegy 19 'To his Mistress Going to Bed' uses the metaphor of exploration, of the ownership of land and the wealth of land, to articulate the sexual:

Licence my roaving hands, and let them go, Before, behind, between, above, below, 
O my America! my new-found-land,

My Kingdom's safest, when with one man man'd.

My Myne of precious stones: My Emperie,

How am I blest in thus discovering thee ${ }^{21}$

A radical implication of the woman-as-land trope is evident in some twentiethcentury literature exploring colonialism. In “Act of Union” Seamus Heaney depicts colonized Ireland as a victim of rape. Ireland is female ('Your back is a firm line of eastern coast / And arms and legs are thrown / Beyond your gradual hills') and the voice of the poem is male and English, speaking of invasion in terms of sexual penetration:

And I am still imperially

Male, leaving you with the pain,

The rending process in the colony,

The battering ram, the boom burst from within.

Una's land is terrorized by the dragon of Roman Catholicism and Redcrosse as the English St. George must free her from its influence. This is Protestant appropriation of the Irish Catholic myth of St. Patrick eradicating snakes from Ireland. In Redcrosse is conflated the roles of St. Patrick and St. George, both of whom cleansed the land of the serpent/dragon. For Spenser the land belongs to Elizabeth, idealized here as the beautiful pale young lady. The fiend Satan, that is the Roman Catholic church, is her enemy and is manifested in the actions of her rebellious Irish subjects supported by Catholic Europe.

\section{Demonizing the Other}

\section{i) Error and the Irish Catholics}

By contrast with Una, who is associated with light, the figure of Error constitutes all that is dark and menacing. Error is both physically and morally repulsive and it takes the brightness of Redcrosse's Christian armour to illuminate her dark den:

By which he saw the vgly monster plaine,

Halfe like a serpent horribly displaide,

But th'other halfe did womans shape retaine, Most lothsom, filthie, foule, and full of vile disdaine.

$$
\text { (I.1.14.6-9) }
$$

Evidence for Error's gross sexual appetite can be found in her monstrous brood:

Of her there bred 
A thousand yong ones, which she dayly fed, Sucking vpon her poisonous dugs, eachone Of sundry shapes, yet all ill fauored:

$$
\text { (I.1.15.4-7) }
$$

The depiction of Error and her young seems to be indicative of negative English attitudes toward Ireland and the Irish. In an essay on the sexualizing of Ireland in Early Modern England, Ann Rosalind Jones and Peter Stallybrass refer to the English writers Fynes Moryson and Barnaby Rich who saw snake-like slipperiness and deception in the attempts by the Irish to conceal themselves from the colonialists. This concealment occurred on many levels: in the Irish landscape, through language, and through literal concealment of the body by way of the glib and the mantle. 23 From Aesop came warnings that the serpent was 'Evil for Good' and 'Cursed Above all Cattle', and admonitions against 'Cherishing a Viper' . ${ }^{24}$ In Richard II Shakespeare invoked the association of the Irish foot-soldiers, or kerns, with serpents: 'We must supplant those rough rugheaded kernes, / Which liue like venome, where no venome else, / But onely they haue priuiledge to liue' (5.771$73)^{.25}$

In England's Eliza (1610) Richard Niccol identified Error's brood as Catholics who presented a threat to English national security: not the Irish but rather those Catholics sent to England by the Pope and Spain (Greenlaw, I, p. 479). Spenser's portrayal of Error and her brood reveals a dread of the progeny of the Other, and a fear that they will continue the fight against the true church.

\section{ii) Error and Irish Catholic Mothers}

The writings of some English commentators on Ireland betray a hostility directed specifically toward Irish women and childbirth. Anxiety about the progeny of the Other is demonstrated in an uneasiness about emissions from women's bodies. In the View Irenius says that the Irish language was learnt by the Old English, descendants of the Anglo-Normans, through the practice of fostering and intermarriage with the native Irish. He uses the metaphor of the mother's milk to illustrate what he regards to be the infectious spread of the Irish language: 'for firste the Childe that suckethe the milke of the nurse muste of necessitye learne his firste speach of her, the which beinge the firste that is envred to his tounge is ever after moste pleasinge vnto him' (Greenlaw, IX, p. 119). The danger is situated in the foster-mother's breast and she transmits her seditious nature to the child: 'they moreouer drawe into themselues togeather with theire sucke even the nature and disposicion of theire nurses...' (ibid.). In A New Description of Ireland Barnaby Rich refers to Irish childbirth with disgust: 'I will not speake of those affaires belonging to Child-bearing women, that are no lesse vnciuill then vncleanly, in many their demeanors belonging to those businesses'. ${ }^{26}$ Fynes Moryson, secretary to Lord Deputy Mountjoy, comments on the unnatural ease of Irish childbirth: 
Some say that commonly the women have little or no pain in child-bearing... they have such easy deliverance, and commonly such strange ability of body presently after it, as I have never heard any woman in the world to have the like...

Error bears the tail of a serpent but 'th'other halfe did womans shape retaine' (I.1.14.8), so presumably she has the breasts, face, and hair of a woman. The serpent that tempted Eve was often represented with the face, and sometimes the upper body, of a woman. Roland Mushat Frye shows that the image of the hybrid female-serpent can be traced back to the late twelfth century where 'we encounter for the first time what was to become an immensely popular and persistent representation - the combination of a serpent's body with a woman's head or torso'. ${ }^{28}$ The presence of the hybrid female-serpent in The Faerie Queene points to a tradition of associating beautiful women with evil and identifying the evil which may lurk within beauty through that part of the creature's body which is not human. This makes for easy identification of Error's degenerate nature, which is more difficult in the case of Duessa because the signs of her degeneracy are not easily read.

The notion of Irish savagery is emphasized in the actions of Error's children who feed on the blood of their dying mother. This corresponds to Pliny's description of the end of the viper's gestation:

After two days she hatches the young inside her uterus, and then bears them at the rate of one a day, to the number of about twenty; the consequence is that the remaining ones get so tired of the delay that they burst open their mother's sides, so committing matricide.

Stories of the savage Irish nature with its supposed history of cannibalism or near cannibalism and love of blood, are evident in the writings of English commentators on Ireland. Concerning the ancestors of the Native Irish, Edmunde Campion in A History of Ireland (1571) relates that

Strabo, the famous geographer, who florished under Augustus and Tiberius Caesar more than fifteen hundred yeares agoe, tellethe (without asseveration) that the Irishe weare great gluttons, eaters of mans fleshe, and counted yt honourable for the parentes deceased to be eaten up of theire children, and that in open sight theye medled with theire wyves, mothers and doughters, which is the less incredible considering what St. Hierom avouchethe of the Scotes, theire ofspring and alies, and what all histories doe witnes of the Scithians, theire auncient founders. 
Writing on Ireland in Holinshed's Chronicles, John Hooker reported that after the defeat of the Papal force in 1580 the people of the area surrounding Smerwick ate the bodies of dead men washed up on shore from a shipwreck, so severe was the extent of the famine after the Desmond rebellion. ${ }^{31}$ The extenuating circumstances of the famine become obscured by the fulfilment of what the English suspected all along, that the Irish are savages. In the View Irenius refers to a scene he has witnessed which endorses this opinion:

... at the execucion of A notable Traitour at Limericke Called murrogh Obrien I sawe an olde woman which was his foster mother take vp his heade whilste he was quartered and sucked vp all the blodd rvnninge theareout Sayinge that the earthe was not worthie to drinke it and thearewith allso steped her face, and breste and torne heare Cryinge and shrikinge out moste terrible

(Greenlaw, IX, p. 112)

O'Brien was executed in 1577 so Spenser was probably in Ireland and so able to witness the execution, or at least hear about it. There is a marked similarity between the execution in Limerick and the action of Error's brood:

Her scattred brood, soone as their Parent deare

They saw so rudely falling to the ground, Groning full deadly, all with troublous feare, Gathred themselues about her body round, Weening their wonted entrance to haue found At her wide mouth: but being there withstood They flocked all about her bleeding wound, And sucked vp their dying mothers blood, Making her death their life, and eke her hurt their good.

$$
\text { (I.1.25.1-9) }
$$

It may be that Spenser recalled what he witnessed at O'Brien's execution when he came to write about Error and her brood. In both passages blood is consumed after decapitation.

Some contemporary English accounts of Irish cannibalism describe a people not naturally disposed to anthropophagy but reduced to such actions through the brutality of war, yet they nevertheless contribute to the English perception of Irish Catholics as savage Other. Accounts of natives indulging in cannibalistic orgies were also reported by those returning from expeditions to the New World, but reference to Irish cannibalism may also be a veiled allusion to the Eucharist and the Catholic belief in transubstantiation. The battle with Error is a defence of Una, who is synonymous with truth and Protestant chastity in the face of sin. This conflict is more straightforward than the later encounter with Duessa because, unlike Error, Duessa is not what she appears to be. Error does not seduce through her own beauty but rather through the beauty of the wood which has brought Redcrosse and Una to her den. 


\section{iii) The Irish Interior: Error's Den and the Saluage Nation}

Error's den is situated in the Wandring Wood but this is more than just a geographical location. The word "error" derives from the Latin errare, "to wander”, and points to the dangers of straying from the path of truth. For Spenser the woods represent danger and the hero's virtue is tested in such an environment. Richard McCabe draws a parallel between Redcrosse's entry into the wood of Error and Spenser's first experience of the Irish campaign: Lord Grey's defeat in the woods of Glenmalure by the O'Byrnes and O'Tooles, whose names Spenser believed signified "woddye” and "hillye”." Whilst the English landscape familiar to Spenser was undergoing extensive deforestation, Ireland was still covered by a considerable amount of woodland which provided shelter for Irish rebels and wild animals and presented a great obstacle to the colonizers. ${ }^{33}$ In an essay on the changes that colonisation brought to the Irish countryside Margaret MacCurtain describes how its destruction made the interior more accessible and provided timber which acted as an inducement to potential settlers.

When Una is led into a forest and almost raped by a pagan knight she is rescued by the creatures who inhabit the woodland to which she has been brought. The Saluage Nation are described as 'A rude, misshapen, monstrous rablement' (I.6.8.7) and it is their gruesome appearance that scares away the would-be rapist. Their reaction to Una is the same as all other reactions to her throughout book 1: 'All stand astonied at her beautie bright, / In their rude eyes vnworthie of so wofull plight' (I.6.9.8-9). Her beauty has the power to transfix observers and because of it she is worshipped by the Saluage Nation: 'The woodborne people fall before her flat, / And worship her as Goddesse of the wood' (I.6.16.1-2). This seems to be an allusion to the Roman Catholic practice of venerating icons. Una must teach the ignorant woodland folk that their worship is profane: 'her gentle wit she plyes, / To teach them truth, which worshipt her in vaine, / And made her th'Image of Idolatryes' (I.6.19.5-7). The creatures are ignorant and worship with 'feeble' eyes, meaning they do not understand the truth she represents. Correction takes time: 'But when their bootlesse zeale she did restraine / From her own worship, they her Asse would worship fayn' (I.6.19.8-9). Spenser creates a fantasy of Truth, the English Protestant church and state, being welcomed by friendly savages who are ignorant of the correct means of worship. They are unable to recognize the truth of Protestantism, but are nevertheless eager to listen and willing to learn. Una's encounter with this Saluage Nation locates her as the learned teacher among the savages. An alien in this environment, she is accepted nonetheless as their educator. 


\section{Duessa and the Infidels}

The demonization of Irish Catholics evident in Spenser's presentation of Error and her brood is also evident in his construction of Duessa as one of Una's most dangerous enemies. Via Duessa, Spenser manipulates the strength of feeling against victims (mostly women) of witch-hunts throughout Europe and, by associating her with Catholicism, exploits anti-Catholic feeling in sixteenthcentury England. Duessa is more dangerous than Error because it is more difficult to penetrate the mask of beauty within which she hides a rotten interior. When Duessa first appears she is in the company of a 'faithlesse Sarazin' (I.2.12.6) and in this way Catholicism is associated with the infidel. As Richard McCabe comments of Book 5, 'The Christian/Paynim dichotomy provides Spenser with a means of organising his political allegory. The 'pagans' of romance fiction are the Catholics of reformed politics'. ${ }^{35}$ The description of Duessa is a close parallel to that of the Whore of Babylon:

He had a faire companion of his way, A goodly Lady clad in scarlot red, Purfled with gold and pearle of rich assay,

And like a Persian mitre on her hed

She wore, with crownes and owches garnished, The which her lauish louers to her gaue;

Her wanton palfrey all was ouerspred

With tinsell trappings, wouen like a waue,

Whose bridle rung with golden bels and bosses braue.

(I.2.13.1-9)

The Revelation describes the Whore of Babylon as 'araied in purple \& skarlat, \& guilded with golde, \& precious stones, and pearles, [with] a cup of golde in her hand, ful of abominations, and filthines of her fornication' (17.4). The allusion to the Whore of Babylon is further extended when Duessa becomes the mistress of Orgoglio (I.7.16-18). The Geneva Bible commentary represents the Catholic/Protestant religious debate in terms of gender: 'Antichrist is cõpared to an harlot because he seduceth $\mathrm{y}^{\mathrm{e}}$ worlde with vaine wordes, doctrines of lies, \& outwarde appearace' and explains that 'This woman is the Antichrist, that is, the Pope with $\mathrm{y}^{\mathrm{e}}$ whole bodie of his filthie creatures ... whose beautie onely standeth in outwarde pompe \& impudencie and craft like a strumpet'.

The Pope as head of the Catholic church, a position which is strictly male, is figured as a whore, an epithet which is strictly applied to the female. D. Douglas Waters has pointed to a widespread tendency in the Protestant religious writings of Elizabethan England to use witchcraft and the figure of the whore as a generalized metaphor for Roman Catholic seduction. ${ }^{37}$ Duessa is physically beautiful and, like the Roman Catholic Church with its use of pageant and spectacle, she is visually seductive. According to its critics the outward appearance of Roman Catholicism hid an inherent moral degeneracy. The 
identification of Duessa with Roman Catholicism was made by James VI of Scotland who read Book 5 as an indirect attack on himself via his mother, Mary Queen of Scots, and called for the arrest and punishment of the poet. Spenser went unpunished but distribution of the second part of The Faerie Queene was banned in Scotland. McCabe believes that this was only a sensitive issue for James during the succession problem and notes that once established on the English throne James did nothing to prevent the publication of the 1609 folio edition of The Faerie Queene.

Duessa is the opposite of Una whose outward beauty is a manifestation of inner goodness. As a witch she is an agent of the devil and, as A. C. Hamilton notes, her name suggests that she is two-faced, a "Double Being" whose beauty masks a rotten interior. ${ }^{39}$ Roland M. Smith makes a convincing case for "Duessa" being an English corruption of an Irish name, a compound of Dub, "black", and Ésa, a woman's name which features in Irish legends and was associated with vice (Smith, p. 918). Duessa's promise of moral integrity is only "seeming" (I.2.37.2), that is, she presents a false appearance and because her appearance is a lie she is an enemy of Truth. When she first meets Redcrosse Duessa does not reveal her true self but rather lies about her name. She calls herself Fidessa, which is ironic because, according to Hamilton, it denotes "being faith" from the Latin fides (faith) and esse (being) (Hamilton, p. 50). Her nominal faithfulness, like her beauty, is a pretence and she carefully manipulates outward signs of virtue in order to deceive Redcrosse.

Duessa's true nature is revealed in the inset story of Fradubio and his lady Fraelissa. Fradubio exhibits moral weakness when he begins to compare the physical appearance of Duessa with that of his own lady:

So doubly lou'd of Ladies vnlike faire, Th'one seeming such, the other such indeede, One day in doubt I cast for to compare, Whether in beauties glorie did exceede; A Rosy girlond was the victors meede:

Both seemde to win, and both seemde won to bee, So hard the discord was to be agreede.

Fraelissa was as faire, as faire mote bee,

And euer false Duessa seemde as faire as shee.

$$
\text { (I.2.37.1-9) }
$$

In this beauty contest Fradubio betrays his arrogance and thus his vulnerability to the guile of Duessa. Both Redcrosse and Fradubio judge by appearances only, which stimulates their lust thus making them weak and morally confused. By abandoning Una in the mistaken belief that she is wanton and becoming Duessa's companion, Redcrosse rejects Truth in favour of falsehood and this is mirrored in Fradubio's desertion of the morally upright Fraelissa. It may be that this is an allegory of the English experience in Ireland. The Old English, descendants of the Anglo-Normans who invaded Ireland in the twelfth century, were often accused by the New English of "going native", of being seduced and contaminated by Native Irish culture. This was viewed by the New English in Ireland as a betrayal of their superior English nature, a rejection of their Englishness. In the View 
Irenius says that 'the moste parte of them are degenerated and growen allmoste meare Irishe yea and more malitious to the Englishe then the verye Irishe themselves' (Greenlaw, IX, p. 96). When Duessa’s rotten interior is imaginatively cast onto the exterior of the truly beautiful Fraelissa her 'forged beauty' (I.2.36.1) usurps Fraelissa's natural, and therefore God-given, beauty which identifies her as a surrogate for Una, the symbol of English Protestant Truth.

Duessa constantly changes sexual partners and this promiscuity is not only indicative of her fallen moral nature and lack of spiritual faithfulness, but also suggests venereal disease. Her evil is contagious, spreading its influence amongst the wholesome and corrupting the good. The figure of the "whore and the witch" as a generalized metaphor for Roman Catholic seduction is again brought into play as a threat to good Christians like Redcrosse and Fradubio. In his study of witchcraft in Tudor and Stuart England, Alan MacFarlane states that envy and lust were both associated with the witch. ${ }^{40}$ These vices are evident in Duessa's contrary physical states: lust in the beautiful form she adopts so as to lure her victims and envy when she appears as she really is and as a typical witch, old and ugly. Fradubio describes Duessa in her true shape:

Her neather partes misshapen, monstruous,

Were hidd in water, that I could not see,

But they did seeme more foule and hideous,

Then womans shape man would beleeue to bee.

$$
\text { (I.2.41.1-4) }
$$

She is 'a filthy foule old woman' (I.2.40.8), a 'diuelish hag' (I.2.42.1), and her voluntary stripping here anticipates the humiliation of her public stripping later which draws upon the stripping of the Whore of Babylon in the Revelation (17.16). Fradubio's revulsion is centred on Duessa's anal/genital area and so his disgust toward the old woman is one of sexual loathing. Significantly, "devil marks" were often found on a witch's breasts or genital area ${ }^{41}$ The old woman is the antithesis of the idealized young woman and just as youth implies beauty so a lack of youth implies ugliness.

Spenser presents Una as an idealized surrogate of Elizabeth as "Truth", the head of the English Protestant Church and people. Yet Una is also an idealized allegorical representation of Ireland which allows Spenser to show both the colonizer and the colonized landscape itself endorsing the subjugation of the Irish. The depiction of Error and her young constructs the Irish as snake-like and reveals a dread of the savage progeny of the Other. Similarly Duessa as the enemy of Truth and the Whorish witch represents the threat of contamination and seduction by Roman Catholicism of good Protestant knights.

In Book 1 of The Faerie Queene Spenser demonstrates an aesthetic of beauty and/or grotesqueness which reveals an anxiety about the Other. This anxiety is manifested in images of threatening and unpredictable female sexuality and it provokes attempts at containment within images of the Neoplatonic ideal. In Spenser's allegory ugly female forms represent the malevolent whilst beautiful women represent either spiritual and moral goodness or else spiritual and moral 
depravity. Female beauty cannot of itself be trusted for it is potentially deceptive and only the faithful can read the signs. If women cannot be trusted, English colonialist writings seem to say, neither can the Irish. Spenser's anxiety about the potentially deceptive nature of female beauty, an anxiety concerning female sexual power, is related to anxieties about the nature of the political power of the Other. By drawing parallels between Spenser's poem and other writings from this period we may raise questions concerning contemporary attitudes toward demonized groups, the Irish and women, and the role of the beauty metaphor in a work that is both imaginative and political.

\section{Joan FITZPATRICK}

\section{N O T E S}

1. See Edwin Greenlaw, Charles Grosvenor Osgood, and Frederick Morgan Padelford, eds, The Works of Edmund Spenser: A Variorum Edition, 11 vols (Baltimore: Johns Hopkins Press, 1932), I, pp. 422-95.

2. A View of the Present State of Ireland was first attributed to Spenser thirty four years after his death by James Ware, its first editor. Attention has recently been drawn to the fact that scholars have accepted Ware's attribution without question even though direct bibliographical evidence is lacking (Jean R. Brink, 'Constructing the View of the Present State of Ireland', Spenser Studies: A Renaissance Poetry Annual, 11 (1990), 203-28). Until a thorough analysis has been made of the extant manuscripts the question cannot be resolved, but by drawing parallels between it and The Faerie Oueene I hope to support the case for Spenser as the author of the View.

3. By "Other" I refer to Simone de Beauvoir's concept of the expression of a duality, that of the Self and the Other. This operates in the location of woman as "the second sex", by which woman is positioned as the negative, the inessential, in contradistinction from the male. The notion of the Self and the Other is also expressed in group identification (for example nationalism and Protestantism) 'Thus it is that no group ever sets itself up as the One without at once setting up the Other over against itself' (The Second Sex, trans. and ed. by H. M. Parshley (London: Jonathan Cape, 1953), p. 17).

4. Thomas Warton, Observations on the Fairy Queen of Spenser, 2nd edn, 2 vols (London: R. and J. Dodsley, 1762), II, p. 101.

5. Josephine Waters Bennett, The Evolution of The Faerie Queene (New York: Burt Franklin, 1942), pp. 108-23.

6. Naseeb Shaheen, Biblical References in The Faerie Queene (Memphis: Memphis State University Press, 1976), pp. 17-18. Of the twenty eight editions of the complete Bible published in English from 1576 to 1586 twenty one were the Geneva Bible and only seven the Bishops' version.

7. Lawrence Rosinger, 'Spenser's Una and Queen Elizabeth', English Lanquaqe Notes, 6 (1968), 12-17 (p. 13). Rosinger also states that a poem thought to be by John Boys, from a collection published at Cambridge in 1603, praises Elizabeth with reference to her motto by the ambiguous repetition of 'Una' so that it seems like a name, (p. 14). A link between the name 'Una' and Elizabeth I is made by C. Bowie Millican who refers to 'Carminum Sylua', a Latin poem written by Thomas Drant in praise of Elizabeth where he refers to her as 
'virtutibus vna, / Vna meam minuens musam'. Millican supports his conclusion with reference to Richard Harvey who described Elizabeth as the 'Vna of all the women in the earth' in Philadelphus, or A Defence of Brutes, and the Brutans History (C. Bowie Millican, 'Spenser's and Drant's poetic names for Elizabeth: Tanaquil, Gloriana, and Una', Huntington Library Quarterly, 2 (1939), 251-63 (pp. 252, 261)).

8. Roland M. Smith, 'Una and Duessa', Publications of the Modern Language Association of America, 50 (1935), 917-19 (p. 917).

9. All quotations of Spenser's works are from Greenlaw's Variorum edition, see note 1.

10. Roy Strong, Gloriana: The Portraits of Queen Elizabeth I (London: Thames and Hudson, 1987), p. 21.

11. All quotations of the Bible are from The Geneva Bible (Geneva: R. Hall, 1560).

12. Helen Hackett, Virgin Mother, Maiden Queen: Elizabeth I and the Cult of the Virgin Mary (Basingstoke: Macmillan, 1995), pp. 135-36, quotes Edward Hellwis who in A Marvell Deciphered (1589), his commentary on Chapter 12 of Revelation, indicates that he regards the Woman Clothed with the Sun to be both Elizabeth and the Church of England.

13. William Camden, Britain, or a Chorographicall Description of England, Scotland, and Ireland, Beautified with Mappes, Trans. P. Holland (London: G. Bishop and J. Norton, 1610), p. 61, Sig. Ffff.

14. With reference to Irenius's account of what occurred at Smerwick in the View Pauline Henley claims that Irenius is 'voicing Spenser's own sentiments' (Spenser in Ireland (Dublin: Cork University Press, 1928) p. 29). Similarly Judson, in his life of Edmund Spenser, refers to Irenius as Spenser’s 'mouthpiece' (Greenlaw, XI, p. 92).

15 See Gordon Williams, A Dictionary of Sexual Language and Imagery In Shakespearean and Stuart Literature, 3 vols (London: Athlone, 1994), II, pp. 621-24.

16. C. Litton Falkiner, Illustrations of Irish History and Topography, Mainly of the Seventeenth Century (London: Longmans, 1904), pp. 349-50. Falkiner's transcription in full of Gernon's manuscript (Stowe MSS. vol. 28, folio 5) is the earliest printed edition of Gernon's Discourse.

17. Andrew Hadfield and John McVeagh point out that when referring to sixteenth and seventeenth-century colonizers of Ireland the term "English" is inadequate and we "should include Scottish adventurers, French Huguenot refugees, Dutch Protestants and others' (Andrew Hadfield, and John McVeagh, eds, Strangers to That Land: British Perceptions of Ireland from the Reformation to the Famine, Ulster Editions and Monographs, 5 (Gerrards Cross, UK: Colin Smythe, 1994), p. 16). Whilst I acknowledge its shortcomings, for the sake of brevity, I will use the term "English".

18. Walter Ralegh, The Discoverie of the Large, Rich, and Bewtifvl Empire of Gviana, with a Relation of the Great and Golden Citie of Manoa (which the Spanyards call El Dorado) and the Prouinces of Emeria, Arromaia, Amapaia and other Countries, with their Riuers, Adioyninq (London: Robert Robinson, 1596), p. 96, sig. N4v.

19. Louis Montrose, 'The Work of Gender in the Discourse of Discovery', in New World Encounters, ed. by Stephen Greenblatt (Berkeley: University of California Press, 1993), pp. $177-217$ (p. 188). 
20. Cesare Ripa, Iconologia: Or, Moral Emblems (London: P. Tempest, 1709), figs. 212, 209, 185.

21. John Donne, Poems, 7th edn (London: Henry Herringman, 1669), p. 98, sig. Hlv

22. Seamus Heaney, North (London: Faber and Faber, 1975), p. 49.

23. Ann Rosalind Jones, and Peter Stallybrass, 'Dismantling Irena: The Sexualizing of Ireland in Early Modern England', in Nationalisms and Sexualities, ed. by Andrew Parker, et al. (New York: Routledge, 1992), pp. 157-71 (pp. 164-5).

24. Aesop, Fables of Aesop, trans. by S. A. Handford, Penguin Classics (Harmondsworth: Penguin, 1964), pp. 55, 56, 89.

25. Stanley Wells, et al., eds, William Shakespeare: The Complete Works, Original-Spelling edn (Oxford: Clarendon Press, 1986).

26. Barnaby Rich, A New Description of Ireland: Wherein is Described the Disposition of the Irish whereunto they are Inclined (London: Thomas Adams, 1610), p. 24, Sig. E4v.

27. Falkiner, Illustrationsof Irish History and Topography, Mainly of the Seventeenth Century, p. 318. Volume 4 of Moryson's Itinerary contains a brief summary of twenty-five unfinished chapters. Parts of the manuscript of these chapters, not printed in the Itinerary, were edited by Charles Hughes and published in Shakespeare's Europe: Unpublished Chapters of Fynes Moryson's Itinerary, Being a Survey of the Condition of Europe at the end of the 16th Century (London: Sheratt \& Hughes, 1903). Falkiner's edition includes material omitted by Hughes, this includes my quotation.

28. Roland Mushat Frye, Milton's Imagery and the Visual Arts: Iconographic Tradition in the Epic Poems (Princeton: Princeton University Press, 1978), p. [103].

29. Pliny, Natural History, trans. by H. Rackham, Loeb Classical Library, 10 vols (London: Heinemann, 1940), III, p. 401, bk. 10, canto 82, lines 171-76.

30. Edmunde Campion, Two Bokes of the Histories of Ireland, Ed. A.F. Vossen (Assen: Van Gorcum, 1963), p. [21], f. 18v. The passage that Campion refers to is in Strabo's, Geography, trans. by Horace Leonard Jones, Loeb Classical Library, 8 vols (London: Heinemann, 1923), II, 4.5.4.

31. Raphael Holinshed, The First and Second Volumes of Chronicles. (The Third Volume.) Newlie Augmented and Continued by J. Hooker aliàs Vowell Gent. and Others (London: A. Fleming; F. Thin [i.e. Thynne; and J. Stow.], 1587), sig. Rjv -Rijr.

32. Richard A. McCabe, 'Edmund Spenser, Poet of Exile', Proceedings of the British Academy: 1991 Lectures and Memoirs, 80 (1993), 73-103 (p. 83).

33. D. B. Quinn, and K. W. Nicholls, 'Ireland in 1534', in A New History of Ireland, ed. by T. W. Moody, F. X. Martin, and F. J. Byrne (Oxford: Oxford University Press, 1976), III, pp. 1-38 (p. 36).

34. Margaret MacCurtain, Tudor and Stuart Ireland, The Gill History of Ireland (Dublin: Gill and Macmillan, 1972), pp. 89-113. 
35. Richard A. McCabe, 'The Fate of Irena: Spenser and Political Violence', in Spenser and Ireland: An Interdisciplinary Perspective, ed. by Patricia Coughlan (Cork: Cork University Press, 1989), pp. 109-25 (p. 112).

36. The Geneva Bible, p. 120, Sig. GGg4r, notes b and f.

37. He gives as an example Henry Bullinger's A Hundred Sermons upon the Apocalipse (trans. 1561) in which Bullinger states that by the 'inchauntmentes' of Rome, 'all nations have been seduced'; similarly Augustine Marlorat in A Catholike Exposition upon the Reuelation of Sainct John (trans. 1574) refers to Rome as the scarlet whore or anti-Christ and her 'sorcerie, which betokeneth hir superstitous religion, hir whorish doctrine, and hir miracles wrought by diuelish practices...' (D. Douglas Waters, 'Errour's Den and Archimago's Hermitage: Symbolic Lust and Symbolic Witchcraft', Enqlish Literary History, 33 (1966), 279-298 (pp. 281-2)).

38. Richard A. McCabe, 'The Masks of Duessa: Spenser, Mary Queen of Scots, and James VI', English Literary Renaissance, 17 (1987), 224-42 (p. 224). See also Willy Maley, A Spenser Chronology, Author Chronologies (Basingstoke: Macmillan, 1994), pp. 67-8.

39. A. C. Hamilton, ed., Edmund Spenser: The Faerie Queene, Annotated English Poets (London: Longman, 1977), p. 52.

40. Alan MacFarlane, Witchcraft in Tudor and Stuart England: A Regional and Comparative Study (London: Routledge \& Kegan Paul, 1970), p. 215.

41. Rossell Hope Robbins, The Encyclopedia of Witchcraft and Demonology (London: Peter Nevill, 1959), pp. 135-37. 